\title{
Impact of some alternative methods to chemical control in controlling aphids (Hemiptera: Sternorrhyncha) and their side effects on natural enemies on young Moroccan citrus groves
}

\author{
Moulay Chrif Smaili • Lahcen El Ghadraoui • \\ Fatima Gaboun • Rachid Benkirane • \\ Abdelali Blenzar
}

Received: 2 February 2013 / Accepted: 16 December 2013 / Published online: 10 January 2014

(C) The Author(s) 2014. This article is published with open access at Springerlink.com

\begin{abstract}
Aphid control in Moroccan citrus orchards is based mainly on carbamate and neonicotinoid sprays, especially methomyl and imidacloprid. The extensive use of these insecticides may have side effects on natural enemies and environment quality and raises human health concerns. This research aimed to assess the control of aphids with insecticidal soap, kaolin and augmentative biological control using the indigenous predator Adalia decempunctata L. (Coleoptera: Coccinellidae). The insecticides were applied and the predators were released in April 2009 and 2010. Under field
\end{abstract}

M. C. Smaili $(\bowtie)$

Regional Agricultural Research Center, National Agricultural Research Institute, Kenitra, Morocco

e-mail: csmaili@yahoo.fr

L. El Ghadraoui

Faculty of Sciences and Technology, University Sidi

Mohamed Ben Abdellah, Fes, Morocco

F. Gaboun

Regional Agricultural Research Center, National Agricultural Research Institute, Rabat, Morocco

R. Benkirane

Faculty of Sciences, University Ibn Tofail, Kenitra, Morocco

\section{A. Blenzar}

Faculty of Sciences, University Moulay Ismail, Meknes, Morocco experimentation, the methomyl and imidacloprid foliar pulverization were very effective against aphids. In contrast, the insecticidal soap and kaolin application were less efficient while $A$. decempunctata adults were effective only in the first week after release. The side effects on beneficial insects were also assessed and discussed. The possibility of employing $A$. decempunctata in an integrated pest management package in citrus groves is discussed in relation to effectiveness and side effects on beneficial arthropods.

Keywords Adalia decempunctata $\cdot$ Aphididae Beneficial species · Biological control · Imidacloprid · Kaolin · Soaps

\section{Introduction}

In Morocco, the citrus industry plays a very important socio-economic role with a total acreage of approximately 105,000 ha and an estimated production of $1,500,000$ tons per year. In addition, the citrus industry provides an important source of foreign currency, amounting to approximately 0.27 billion euros per year (MAPM 2008). It also generates important employment of about 21 million work-days per year including 12 million in orchards and 9 million in the packing and 
processing segments and many other related industries. The last agreement between the government and citrus growers on the development of the citrus industry was to implement a program aiming to renew old citrus plantations and extend new plantings to 50,000 ha (MAPM 2008).

In Morocco, several pests limit citrus production and can cause significant damage when conditions are favorable for the pests. Besides scales, medfly, mites and snails, aphids also are major pests, with negative effects on citrus productivity (Mazih 2011). In Morocco, the aphid species that infest citrus orchards are: spirea aphid Aphis spiraecola Pach, black citrus aphid Toxoptera aurantii Boyer de Fonscolombe, melon aphid Aphis gossypii Glover, green peach aphid Myzus persicae Sulzer, black bean aphid Aphis fabae Scopoli, and cowpea aphid Aphis craccivora Koch (Hemiptera : Aphididae) (Sekkat 2008; Smaili et al. 2001, 2008; Vittorio \& Delucchi 1964). However, the brown citrus aphid Toxoptera citricida Kirkaldy (Hemiptera: Aphididae), which is a major citrus aphid pest in the northern part of the Mediterranean zone, mainly in Portugal and Spain (Nieto-Nafría et al. 2005; EPPO 2006; Ilharco and Sousa-Silva 2009), currently does not exist in Morocco. In the Gharb area (northwest of Morocco), only the first three species are considered the most important citrus pests (Smaili et al. 2009). When conditions are favorable, these species can cause significant damage, especially to young citrus plantations, causing falling and growth stunting (Michaud \& Browning 1999). The two species T. citricida and $A$. gossypii are the main vector of CTV (Citrus tristeza closterovirus (Closterovirus: Closteroviridae) (EPPO 2004; Nieto-Nafría et al. 2005). However, A. spiraecola and $T$. aurantii can also, to a lesser extent, be CTV vectors (Yokomi \& Garnsey 1987).

In the Gharb area and during certain years, aphids were considered as secondary pests in the old citrus orchards because the shoot infestations were very low (Smaili et al. 2009), whereas in young citrus plantations aphids are considered primary pests and damage often is visible - requiring several chemical applications during the same year. In Morocco, an insecticide mix based on imidacloprid and methomyl (and sometimes with endosulfan), is currently used to control aphids in citrus groves. Methomyl belongs to the carbamate class, widely used for controlling insects by inhibiting the enzyme acetylcholinesterase which hydrolyzes the neurotransmitter acetylcholine. Imidacloprid is a neonicotinoid substance which acts agonistically on the insect nicotinic acetylcholine receptor as molecular target and works by interfering with the transmission of nerve impulses in insects (Mencke \& Jeschke 2002).

In Morocco, these products are listed among the active ingredients recommended for controlling citrus aphids (AMPP 2013). However, many efforts have been made to switch from chemical control to integrated pest management (IPM) on citrus. In this context, several socalled natural and commercial products compatible with IPM often are considered to be effective and recommended in controlling aphids in young citrus plantations, without taking into account their side effects and selectivity on the natural enemies. This is the case with insecticidal soap which acts on foliar insects by contact, dissolving their outer envelopes and causing the insect to dry up and die. It is also the case of kaolin, a natural mineral product in the form of fine white powder, which was reported as effective against several pest Lepidoptera (Jaastad et al. 2006; Sackett et al. 2005), beetles (Showler 2002), mites (Jaastad et al. 2006), fruit flies (Braham et al. 2007; Mazor \& Erez 2004; Saour \& Makee 2004; Villanueva \& Walgenbach 2007), thrips (Larentzaki et al. 2008) and aphids (Karagounis et al. 2006; Wyss \& Daniel 2004). On the other hand, an augmentative biological control technique using especially native species often has been reported as a potential method to control some pests (Cock et al. 2009; Crowder 2007; Iperti 1999; Michaud 2001; Van Lenteren \& Bueno 2003).

This work is part of an IPM program against citrus aphids and other pests in the Gharb region, and has two objectives: to evaluate the efficacy of insecticidal soap, kaolin and augmentative biological control using $A$. decempunctata on young citrus plantations; and to assess side effects on beneficial insects under field trial.

\section{Materials and methods}

Area and field trial The Gharb region is located in the northwestern part of Morocco. The climate is Mediterranean with an average annual rainfall ranging from $430 \mathrm{~mm}$ to $520 \mathrm{~mm}$ and mean temperatures between $13{ }^{\circ} \mathrm{C}$ in winter and $27{ }^{\circ} \mathrm{C}$ during the summer. The experiment was conducted in a 1.1 ha citrus grove of 5-year-old clementine trees (Citrus reticulata Blanco), planted at a spacing of $4 \mathrm{~m} \times 5 \mathrm{~m}$ (354 trees $\mathrm{ha}^{-1}$ ), on a sandy soil located $9 \mathrm{~km}$ from the city of 
Kenitra (Gharb zone). The grove was drip irrigated (daily watering) and received routine fertilizer.

Treatment description Lannate 25WP (25\% methomyl, Amaroc SA, Casablanca, Morocco) was sprayed at a dose of $250 \mathrm{cc} \mathrm{hl}^{-1}$. Confidor (200 g $\mathrm{g}^{-1}$ imidacloprid, Bayer Crop Science, Casablanca, Morocco) was applied at a dose of $50 \mathrm{cc} \mathrm{hl}^{-1}$. Black soap, a natural product derived from olive oil production (soap traditionally produced in Marrakech, Morocco), was used at $\sim 0.2 \mathrm{~kg} \mathrm{hl}^{-1}$. The kaolin-based powdery product is a non-toxic white concentrated fine powder $\mathrm{Al}_{2}\left[(\mathrm{OH})_{2}, \mathrm{Si}_{2} \mathrm{O}_{5}\right]$ (Kaolin formulated product, Agriman Firm, Casablanca, Morocco); $2000 \mathrm{lha}^{-1}$ was applied at a dose of $1.4 \%$. Augmentative biological control involved the release of $A$. decempunctata adults less than one week old with one adult per tree (d1) and four adults per tree (d2) during April of 2009 and 2010, respectively. A. decempunctata larvae were picked in situ from other citrus orchards in the Gharb area where their abundance was high. They fed on aphids ( $A$. spiraecola and T. aurantii) infesting clementine shoots cv 'Cadoux' inside a Plexiglas container $(50 \mathrm{~cm}$ x $51 \mathrm{~cm}$ $\mathrm{x} 40 \mathrm{~cm}$ ) in the entomology laboratory of the Regional Agricultural Research Center (Kenitra, Morocco). They are then kept in a rearing cage until adult emergence. Infested citrus shoots were transplanted into moistened soil to retain their turgor under controlled conditions (25 $\pm 1{ }^{\circ} \mathrm{C}, 70 \%$ r.h.) with natural lighting. Shoots showing signs of weakness were replaced by new ones. Before release in the field, A. decempunctata adults were placed separately and kept without aphid food in the Plexiglas container for $24 \mathrm{~h}$, in order to maximize their predatory reflex toward aphids under the same controlled conditions mentioned above.

Field assays Trials were conducted from March to June in 2009 and 2010. The experiment was conducted as a randomized complete block design, with three blocks. Each block consisted of five treatments which included: methomyl (2009)/imidacloprid (2010): plots with trees sprayed with methomyl (2009) or imidacloprid (2010); insecticidal soap: plots with trees sprayed with the soap; kaolin: plots with trees sprayed with kaolin; and adalia/ d1 (2009) or adalia/d2 (2010): plots with trees where $A$. decempunctata adults were released with a dose $\mathrm{d} 1$ or d2 mentioned above, during 2009 and 2010, respectively; Control: plots with trees sprayed only with water. In each block, each treatment consisted of 14 trees with two rows, of which four were randomly selected. Then on those trees, eight shoots per tree were selected again (32 seedlings per treatment $\times 3$ replications). The young citrus shoot, noted here by "shoot", is easily recognizable by its green color and clear flush or young leaves, which are infested with early and newly formed aphid colonies. In contrast, old citrus shoots are wounded, with a dark green color and are already infested with aphid colonies. The treatments applied were foliar pulverization with a conventional $120 l$ air blaster ground sprayer (Agriman Firm), pulled by a mini tractor (Mark Victor BCS AR 500, 45 HP, Ramioui Firm Sarl, Casablanca, Morocco). One foliar spray of each product listed above was applied in approximately 5-6l per tree during the mornings of April 7, 2009 and April 6, 2010. For each treatment, all rows and trees were covered by the product. This period often coincides with a high number of aphid colonies and citrus flush is very attractive. To avoid interference between treatments, the plots were separated by one row of guard trees. No other insecticide treatments were applied while the trial was performed in the clementine grove.

Monitoring and assessment Aphids: A total of six variables belonging to two categories were recorded at four dates $(5,7,14$ and 21 days) after treatment. The first category referred to the density of aphids (T. aurantii, A. spiraecola and the two species grouped together), and was estimated by the number of aphids per shoot. The second category referred to the level of shoot infestation by aphids (T. aurantii, A. spiraecola and the two species grouped together), and was estimated by dividing the number of infested shoots by the total number of shoots observed (per tree). Each shoot was considered infested when it hosted one or more colonies of T. aurantii, A. spiraecola or both species. Other important aphid species such as $M$. persicae or A. gossypii were absent during these field trials.

Natural enemies were monitored using different methods: On citrus shoots, for each treatment, the number of natural enemies was counted on each citrus shoot used for aphids sampling. Many species of beneficial insects were recorded on Moroccan citrus groves (Smaili et al. 2009, 2010, 2013). The main groups of these beneficial species were the parasitoids (Aphelinidae, Braconidae, Encyrtidae and Eulophidae) and the predators (Coccinellidae, Syrphidae, Nitidulidae, Chrysopidae, Cecidomyiidae, Coniopterygidae and Phytoseiidae). 
The density of each species was estimated by recording the total number on eight shoots (4 observations x 3 replicates). Parasitism was estimated by dividing the number of parasitized aphids by the total number of aphids recorded on eight citrus shoots. With the beating method, in each treatment 12 branches randomly selected were beaten $(12 \times 4$ branches per treatment). To standardize the method, each branch was stricken ten times by a stick fitted at its end with a rubber cover. The natural enemies fell in the jar of the "umbrella trap" containing $70 \%$ alcohol. The density of each species was estimated by counting the total number of species found on the 12 branches ( 4 observations x 3 replicates). The yellow sticky traps were used to follow the hymenoptera species. In each treatment, one trap $\left(20 \times 6 \mathrm{~cm}^{2}\right)$ was suspended on the south side of the tree. The number of species caught in the trap was counted in the laboratory under a binocular microscope. The density of each species caught was estimated by counting the total number in each trap (one observation $\mathrm{x} 3$ replicates). The visual observation method was used for monitoring the hoverfly Episyrphus balteatus DeGeer (Diptera: Syrphidae). Its density was estimated by counting the number of hoverflies moving side by side to each sampling tree during a 15-min period (4 observations x 3 replicates).

Treatment effect and percentage efficacy Effect of treatment was estimated by the rate of reduction (\% Ri) using the following formula: $\mathrm{R}_{\mathrm{i}} \%=\left(1-\mathrm{T}_{\mathrm{i}} / \mathrm{T} \mathrm{O}_{\mathrm{i}}\right) \times 100$ (Abbott 1925; Ullah et al. 2005), where $T_{i}$ is the average of the studied variable " $i$ " (density or infestation) in the treated plots; $\mathrm{T}_{\mathrm{i}}$ is the average of the studied variable " $\mathrm{i}$ " in the untreated control plots. The percentage efficacy control $\left(\mathrm{E}_{\mathrm{i}} \%\right)$ was estimated and computed using the following formula (Henderson \& Tilton 1955) : $\mathrm{E}_{\mathrm{i}} \%=\left[\left(1-\mathrm{T} 0_{\mathrm{i}}\right.\right.$ before treatment $\mathrm{x}$ Ti after treatment $) /\left(\mathrm{T} 0_{\mathrm{i}}\right.$ after treatment $\mathrm{x} \mathrm{T}_{\mathrm{i}}$ before treatment) $\mathrm{x} 100$; with $\mathrm{T}_{\mathrm{i}}$ being average of the studied variable " $i$ " for the control; and $\mathrm{T}_{\mathrm{i}}$ being the average of the studied variable " $\mathrm{i}$ " in the treated plots.

Statistical analysis At each date, ANOVA was used to compare the effect of the treatment on the variables; density of $T$. aurantii; A. spiraecola and aphids; the infestation of shoots per T. aurantii, A. spiraecola and aphids; and finally the densities of different beneficial species recorded. Separation of homogeneous groups (levels of the factor treatment) was made by t-test (LSD at the $P=0.05$ level using the SAS software version 9.1.3 (SAS Institute 2005). Square-root and arcsin (square-root) transformation of the number of aphids and transformation and the infestation of shoots were used to normalize the data.

\section{Results}

Aphid density and shoot infestation During 2009, there was a difference among the mean densities of aphids in the various treatments (Table 1). Five days after product application, the mean aphid density was significantly much lower in the methomyl treatment than in all others. However, this density was similar in the plots sprayed with insecticidal soap, kaolin and the untreated control. The aphid density was also increased in the adalia/d1 treatment to $\sim 99.63 \pm 96.32$. Seven days later, the mean aphid density was significantly lower in the insecticidal soap, kaolin and adalia/d1 treatments than in the untreated control. Although we note that aphids were recorded on shoots previously sprayed with methomyl and aphid density was less in adalia/d1 treatment than others, this reduction was not statistically different among treatments. The mean of shoot infestation was statistically different among treatments during 2009 (Table 2). Five days after product application, shoot infestation increased in the kaolin and adalia/d1 treatments, whereas there were no infested shoots in the methomyl treatment. Two days later, mean shoot infestation was null and low for methomyl and adalia/d1 treatment, respectively (for T. aurantii). At other sampling dates, mean shoot infestation was similar for all treatments.

During 2010, mean aphid density varied among the treatments (Table 3). Five days after treatment application, the mean aphid density in adalia/d2 was similar to the insecticidal soap and kaolin treatments, but statistically less than the control. Seven days later, the aphid density was lower in the adalia/d2 treatment than in the insecticidal soap and kaolin treatments. Two weeks later, imidacloprid and adalia/d2 treatments scored similarly, and were different from kaolin, the insecticidal soap and the untreated control. For the other sampling date, the density was lower in the imidacloprid and adalia/d2 treatments than other treatments, but was not statistically significant compared with the untreated control. Also differences in the mean shoot infestation among treatments were significant (Table 4). Five days 


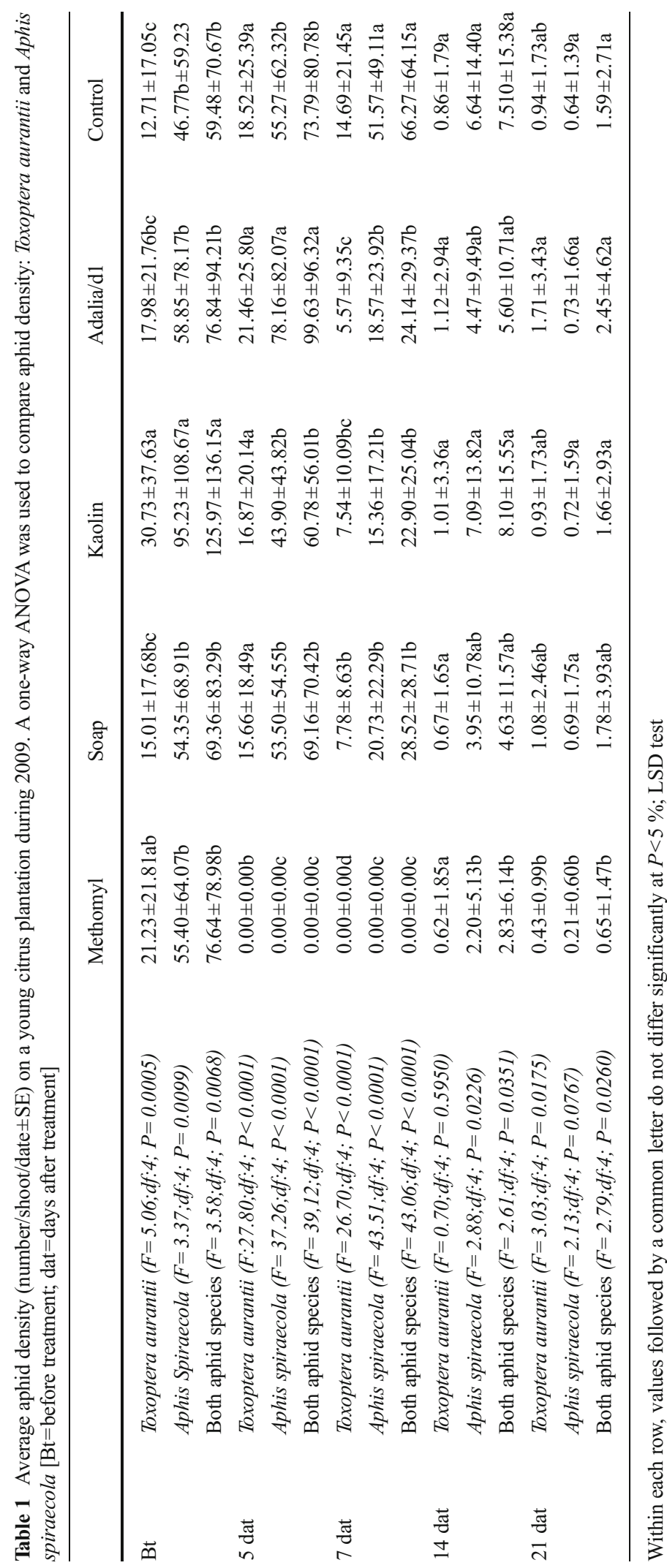




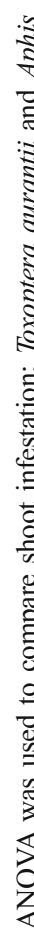

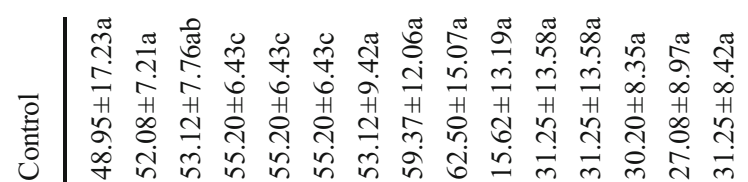

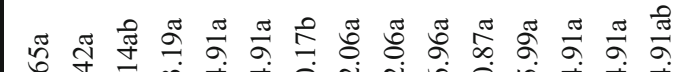

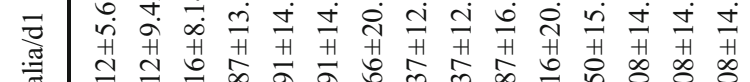

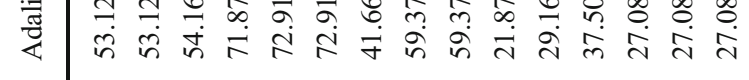

:

운

a

岁

等

常

ॠٓ

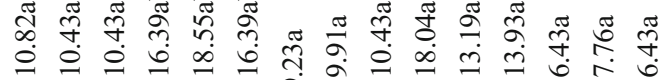

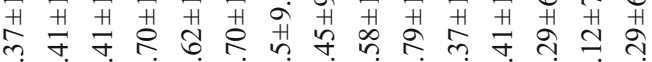

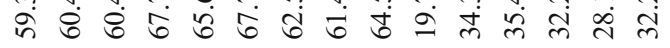

ठิे

羙

. ํㅠ

(n)

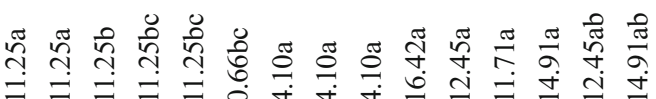

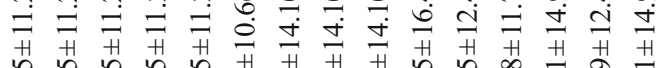

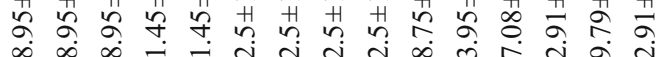

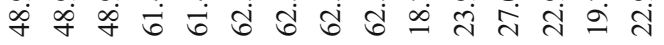

密

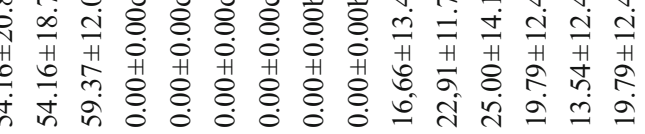

$\frac{\pi}{2}$

喜

照

วิ

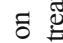

䆥离

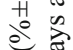

.0ํㅛㄹ

营

웅

党

竞它

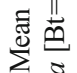

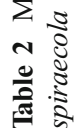

से

ฐิ

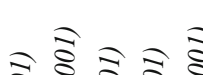

$\widehat{\overline{8}}$

\&े $\approx \infty$

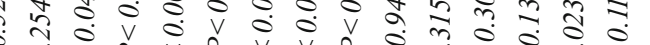

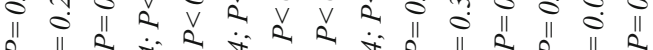

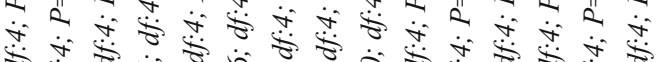

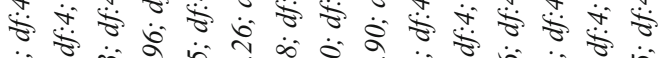

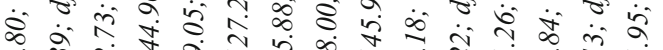

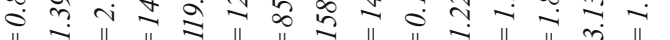

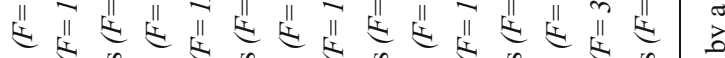

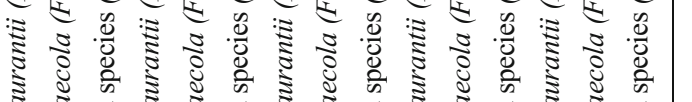

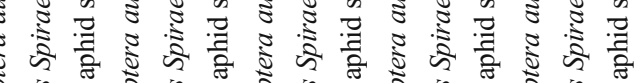

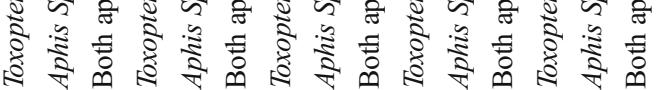

$+$

承

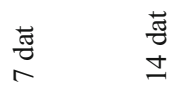

$\frac{\text { त }}{\pi}$ 


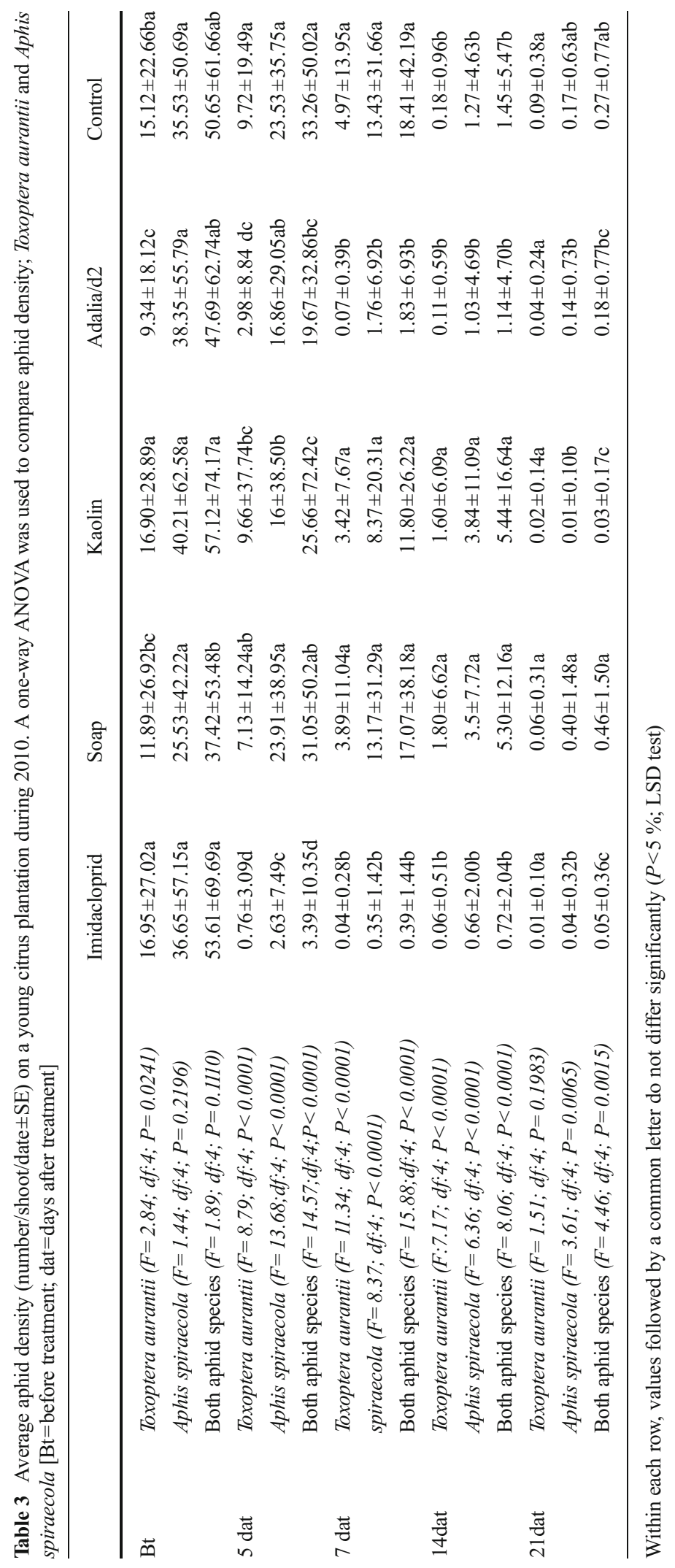




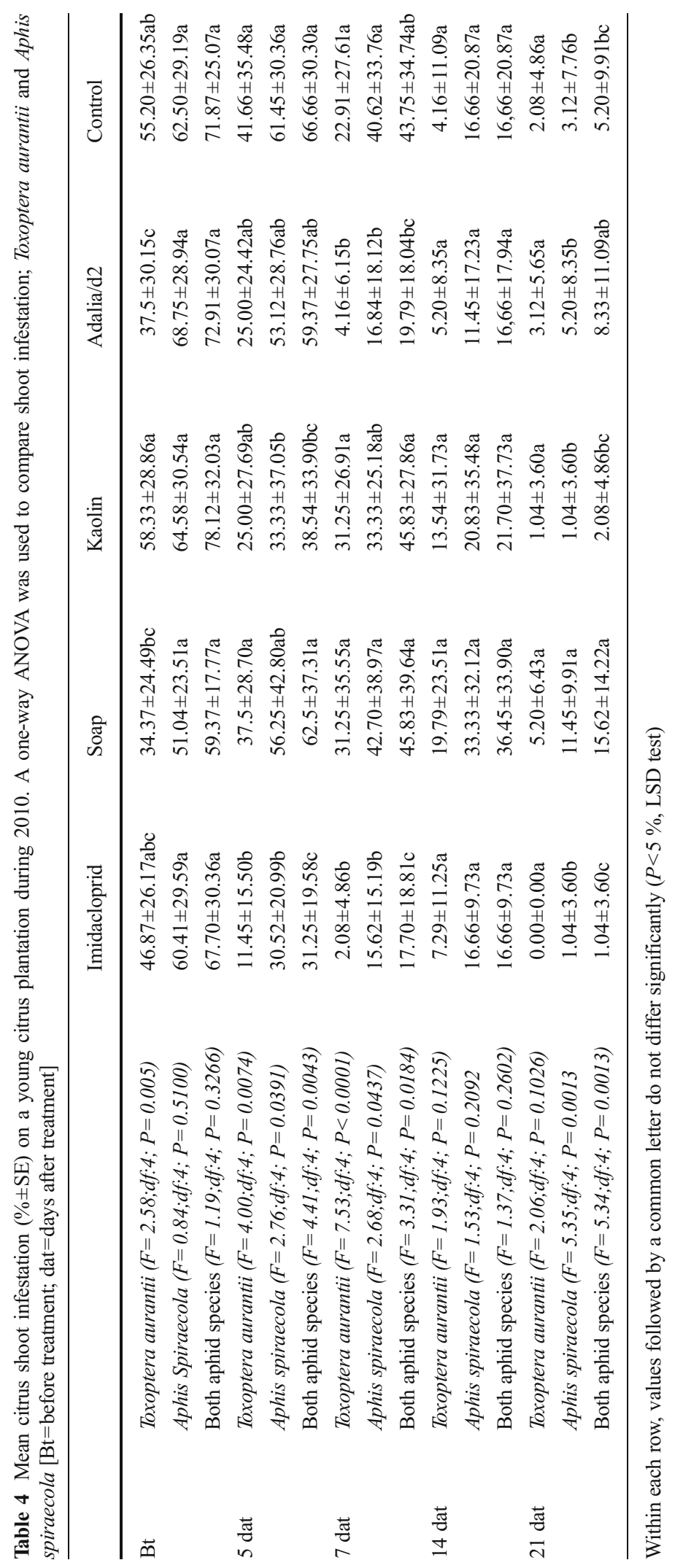


later, no difference was observed among imidacloprid, kaolin, insecticidal soap and adalia/d2 treatments. Two days later, shoot infestation was similar for adalia/d2 and imidacloprid treatments, but statistically lower than others. At the other sampling dates, a heavy shoot infestation was recorded in the plots treated with insecticidal soap and kaolin, but not significantly different from that registered on other treatments.

Effect of treatment Considering mean aphid density, reduction for the methomyl treatment was higher one week after $(100 \%)$ and further decreased (around $60 \%$ ) during 2009 (Table 5). Reduction for the insecticidal soap treatment was very low at first $(6.26 \%)$ and varied later ( $38 \%$ to $57 \%$ ), but became negative for the last sampling. For kaolin, reduction did not exceed $65.4 \%$ for the first week and became negative afterwards. Reduction in the adalia/d1 treatment was $\sim 63.5 \%$ one week later and then became negative. During 2010, reduction was always above $50 \%$ for imidacloprid treatment. Reductions for insecticidal soap and kaolin treatments were low or negative, except for kaolin treatment in the last sampling. Adalia/d2 treatment allowed a great reduction (90.04\%) one week after $A$. decempunctata was released. However, a small reduction was found later, ranging between $21.42 \%$ and $30.76 \%$. Considering mean shoot infestation, reduction for methomyl application was higher (100\%) after one week compared with 2009. This reduction decreased at later dates (20\% and $36.66 \%$ ). During 2010, reduction was variable for the imidacloprid treatment $(0 \%$ and
$80 \%$ (Table 6). The insecticidal soap application showed a low or negative reduction at one week, but an increase of shoot infestation was recorded afterwards. However, in kaolin and adalia/d2 treatments, reduction was low only after one week.

Percentage of efficacy control Considering mean aphid density, methomyl and imidacloprid treatments were very effective during the first sampling date (Table 5). Application of insecticidal soap and kaolin during 2009 had a maximum efficiency of $\sim 63.1 \%$ and $83.6 \%$, respectively, one week after their spreading. However, during 2010, these two products did not seem very effective against aphids (except the last date for kaolin). The efficacy of adalia/d1 and adalia/d2 ranged between $71.7 \%$ and $89.42 \%$ for the first week after $A$. decempunctata release. Regarding shoot infestation, methomyl and imidacloprid were very effective (100\%) and ranged between $57 \%$ and $78.7 \%$, respectively, during the first week. Insecticidal soap and kaolin treatments were not effective in 2009 (13\% and $20 \%$ ) (Table 6). The same was noted during 2010, with a negative efficacy for the insecticidal soap and kaolin treatments. Adalia/d1 treatment was not very effective in $2009(<15 \%)$. However, efficacy of the adalia/d2 treatment should be considered (55.40\%) but only one week after the release of $A$. decempunctata. Effectiveness and percentage reduction varied qualitatively among treatments (Table 7). Methomyl and imidacloprid treatments were very effective followed by the adalia/d2 treatment.

Table 5 Reduction (R\%) and Effectiveness (E\%) treatments applied to the density of aphids: Toxoptera aurantii and Aphis spiraecola $[$ dat $=$ days after treatment $]$

\begin{tabular}{|c|c|c|c|c|c|c|c|c|}
\hline & \multicolumn{2}{|l|}{5 dat } & \multicolumn{2}{|l|}{7 dat } & \multicolumn{2}{|l|}{14 dat } & \multicolumn{2}{|l|}{21 dat } \\
\hline & $\mathrm{R}$ & $\mathrm{E}$ & $\mathrm{R}$ & $\mathrm{E}$ & $\mathrm{R}$ & $\mathrm{E}$ & $\mathrm{R}$ & $\mathrm{E}$ \\
\hline Methomyl & $100 *$ & 100 & 100 & 100 & 62.27 & 70.71 & 58.82 & 68.04 \\
\hline Imidaclopride & $89.79 * *$ & 90.35 & 97.85 & 97.96 & 50.00 & 52.75 & 80.76 & 81.83 \\
\hline \multirow[t]{2}{*}{ Soap } & 6.26 & 19.60 & 56.96 & 63.09 & 38.28 & 47.06 & -11.76 & 4.14 \\
\hline & 6.63 & -26.36 & 7.29 & -25.47 & -263.57 & -392.08 & -73.07 & -134.25 \\
\hline \multirow[t]{2}{*}{ Kaolin } & 17.63 & 61.10 & 65.43 & 83.67 & -7.90 & 49.04 & -4.57 & 50.61 \\
\hline & 22.83 & 31.56 & 35.91 & 43.17 & -273.57 & -231.26 & 88.46 & 89.76 \\
\hline Adalia/d1 & -35.02 & -4.52 & 63.56 & 71.79 & 25.28 & 42.23 & -54.24 & -19.41 \\
\hline Adalia/d2 & 40.83 & 37.17 & 90.04 & 89.42 & 21.42 & 16.55 & 30.76 & 26.47 \\
\hline
\end{tabular}

*; **: Values in 2009 and 2010, respectively. See text for definition and formula of Reduction percentage and Effectiveness percentage 
Table 6 Reduction (R\%) and Effectiveness (E\%) treatments applied for shoot infestation [dat=days after treatment]

\begin{tabular}{|c|c|c|c|c|c|c|c|c|}
\hline & \multicolumn{2}{|l|}{5 dat } & \multicolumn{2}{|l|}{7 dat } & \multicolumn{2}{|l|}{14 dat } & \multicolumn{2}{|l|}{21 dat } \\
\hline & $\mathrm{R}$ & $\mathrm{E}$ & $\mathrm{R}$ & $\mathrm{E}$ & $\mathrm{R}$ & $\mathrm{E}$ & $\mathrm{R}$ & $\mathrm{E}$ \\
\hline Methomyl & $100 *$ & 100 & 100 & 100 & 20.00 & 28.42 & 36.66 & 43.33 \\
\hline Imidaclopride & $53.01 * *$ & 50.24 & 59.05 & 57.03 & 0.00 & -6.15 & 80 & 78.76 \\
\hline \multirow[t]{2}{*}{ Soap } & -13.20 & -22.84 & 0.00 & -8.51 & 13.33 & 5.95 & 26.66 & 20.42 \\
\hline & 6.25 & -13.48 & -4.76 & -26.81 & -118.75 & -164.80 & -200 & -263.15 \\
\hline \multirow[t]{2}{*}{ Kaolin } & -22.64 & -7.83 & 3.33 & 9.13 & -13.33 & 0.34 & -3.33 & 9.13 \\
\hline & 42.18 & 46.81 & -4.76 & 3.61 & -13.25 & -20.75 & 60 & 63.20 \\
\hline Adalia/d1 & -32.07 & -29.53 & 5.00 & 6.82 & -20.00 & -17.69 & 13.33 & 15.00 \\
\hline Adalia/d2 & 10.93 & 12.20 & 54.76 & 55.40 & 0.00 & 1.42 & -60 & -57.71 \\
\hline
\end{tabular}

*; ** Values in 2009 and 2010, respectively. See text for definition and formula of Reduction percentage and Effectiveness percentage

Natural enemies Differences among treatments in the density of beneficial species at each sampling date were significant throughout the monitoring period (Tables 8 and 9). During 2009, the methomyl application reduced the number of natural enemies compared with the other treatments. Coccinellid density was higher in the adalia/ $\mathrm{d} 1$ treatment than in the control after one week. The same observation was made for the lacewing Chrysoperla carnea (Stephens) (Neuroptera: Chrysopidae) in adalia/ d1. No difference was observed among treatments in the density of the syrphid E. balteatus, although the density was relatively higher in the untreated control and adalia/ d1. During 2010, the coccinellid density was lower in imidacloprid-treated trees than in the control. However, if species are considered separately, this density is not significant for all treatments. The density of the lacewing C. carnea was similar for adalia/d2, kaolin and control treatments. The density of spiders was higher for adalia/ $\mathrm{d} 1$ and control treatments during the first week. Parasitized aphids were not observed in our samples during 2009. Except for a maximum of $25.44 \%$ noted at the insecticidal soap treatment, no significant difference was observed among all treatments. During 2010, the hymenoptera density was higher in adalia/d2 and control treatment than in the others.

\section{Discussion}

The imidacloprid and methomyl foliar spray reduced the aphid populations and shoot infestation in young citrus groves compared with untreated control. These products are very effective for controlling aphids, but they reduced the density of the most beneficial species. Methomyl is known for having side effects on several

Table 7 Percentage reduction (R) and Effectiveness (E) classified arbitrarily qualitatively

\begin{tabular}{|c|c|c|c|c|c|c|c|c|}
\hline & \multicolumn{2}{|c|}{ Methomyl/Imidacloprid } & \multicolumn{2}{|c|}{ Adalia/d1/Adalia/d2 } & \multicolumn{2}{|c|}{ Kaolin } & \multicolumn{2}{|c|}{ Soap } \\
\hline & $\mathrm{R}$ & $\mathrm{E}$ & $\mathrm{R}$ & $\mathrm{E}$ & $\mathrm{R}$ & $\mathrm{E}$ & $\mathrm{R}$ & $\mathrm{E}$ \\
\hline \multicolumn{9}{|c|}{ Aphid density } \\
\hline 2009 & +++ & +++ & + & + & + & ++ & + & + \\
\hline 2010 & +++ & +++ & ++ & ++ & ++ & + & + & - \\
\hline \multicolumn{9}{|c|}{ Shoots infestation } \\
\hline 2009 & ++ & ++ & 0 & 0 & 0 & + & + & + \\
\hline 2010 & + & + & ++ & ++ & + & + & 0 & 0 \\
\hline
\end{tabular}

Effectiveness and percentage reduction classified arbitrarily qualitatively in decreasing order $(+++,++,+$ and 0$)$ according to predefined thresholds. See text for definition and formula of Reduction percentage and Effectiveness percentage 
Table 8 Average abundance of natural enemies (number/trap, observation, beating or shoot, $\pm \mathrm{SE})$ and rate of parasitism $(\% \pm \mathrm{SE})$ in a young citrus plantation during 2009. A one-way ANOVA was used to compare natural enemies abundance and rate of parasitism. C. carnea; E. balteatus; Coccinella septempunctata L. (Coleoptera: Coccinellidae); A. decempunctata [dat=days after treatment]

\begin{tabular}{|c|c|c|c|c|c|c|}
\hline & & Methomyl & Soap & Kaolin & Adalia/d1 & Control \\
\hline \multirow[t]{9}{*}{5 dat } & Hymenoptera/sticky trap $(F=114.06 d f: 4 ; P<0.0001)$ & $0.00 \pm 0.00 \mathrm{~b}$ & $0.00 \pm 0.00 \mathrm{~b}$ & $0.00 \pm 0.00 \mathrm{~b}$ & $2 \pm 0.00 \mathrm{a}$ & $2.33 \pm 0.57 \mathrm{a}$ \\
\hline & C. carnea/beating $(F=15.22 d f: 4 ; P<0.0001)$ & $0.00 \pm .0 .00 \mathrm{~b}$ & $0.00 \pm 0.00 \mathrm{~b}$ & $0.00 \pm 0.00 \mathrm{~b}$ & $1.58 \pm 1.16 \mathrm{a}$ & $1.33 \pm 1.15 \mathrm{a}$ \\
\hline & E. balteatus/observation & $0.00 \pm 0.00 \mathrm{a}$ & $0.00 \pm 0.00 \mathrm{a}$ & $0.00 \pm 0.00 \mathrm{a}$ & $0.00 \pm 0.00 \mathrm{a}$ & $0.00 \pm 0.00 \mathrm{a}$ \\
\hline & C. septempunctata/beating $(F=4.43 ; d f: 4 ; P<0.0042)$ & $0.00 \pm 0.00 \mathrm{~b}$ & $0.00 \pm 0.00 \mathrm{~b}$ & $0.00 \pm 0.00 \mathrm{~b}$ & $0.33 \pm 0.49 \mathrm{a}$ & $0.42 \pm 0.51 \mathrm{a}$ \\
\hline & A. decempunctata/beating $(F=2.84 ; d f: 4 ; P<0.0348)$ & $0.00 \pm 0.00 \mathrm{~b}$ & $0.00 \pm 0.00 \mathrm{~b}$ & $0.00 \pm 0.00 \mathrm{~b}$ & $0.5 \pm 0.79 \mathrm{a}$ & $0.42 \pm 0.9 \mathrm{ab}$ \\
\hline & Coccinellidae/beating $(F=5.50 ; d f: 4 ; P<0.0011)$ & $0.00 \pm 0.00 \mathrm{~b}$ & $0.00 \pm 0.00 \mathrm{~b}$ & $0.00 \pm 0.00 \mathrm{~b}$ & $0.83 \pm 1.26 \mathrm{a}$ & $0.83 \pm 0.93 \mathrm{a}$ \\
\hline & Coccinellidae/shoots $(F=28.72 ; d f: 4 ; P<0.0001)$ & $0 \pm 0.00 \mathrm{c}$ & $3 \pm 3.27 \mathrm{c}$ & $4.92 \pm 2.60 \mathrm{~b}$ & $9.5 \pm 3.91 \mathrm{a}$ & $6.67 \pm 2.90 \mathrm{~b}$ \\
\hline & Spiders/beating $(F=3.63 ; d f: 4 ; P=0.0119)$ & $0.33 \pm 0.89 b$ & $1.16 \pm 1.11 \mathrm{ab}$ & $1.41 \pm 1.00 \mathrm{a}$ & $2 \pm 1.48 \mathrm{a}$ & $1.66 \pm 1.5 \mathrm{a}$ \\
\hline & Parasitism & $0.00 \pm .00 \mathrm{a}$ & $0.00 \pm 0.00 \mathrm{a}$ & $0.00 \pm 0.00 \mathrm{a}$ & $0.00 \pm 0.00 \mathrm{a}$ & $0.00 \pm 0.00 \mathrm{a}$ \\
\hline \multirow[t]{9}{*}{7 dat } & Hymenoptera/sticky trap $(F=36.40 d f: 4 ; P<0.0001)$ & $0 \pm 0.00 \mathrm{~b}$ & $0 \pm 0.00 \mathrm{~b}$ & $0 \pm 0.00 \mathrm{~b}$ & $3 \pm 0.00 \mathrm{a}$ & $3.33 \pm 1.52 \mathrm{a}$ \\
\hline & C. carnea/ beating $(F=5.50 ; d f: 4 ; P=0.011)$ & $0.16 \pm 0.38 b$ & $0.41 \pm 0.66 b$ & $0.58 \pm 0.90 \mathrm{~b}$ & $0.83 \pm 1.11 \mathrm{~b}$ & $2.16 \pm 1.74 \mathrm{a}$ \\
\hline & E. balteatus/observation $(F=1.03 d f: 4 ; P=0.4034)$ & $0.00 \pm 0.00 \mathrm{a}$ & $0.16 \pm 0.39 a$ & $0.16 \pm 0.39 \mathrm{a}$ & $0.33 \pm 0.65 \mathrm{a}$ & $0.33 \pm 0.65 \mathrm{a}$ \\
\hline & $\begin{array}{l}\text { A. septempunctata/beating ( } F=10.12 ; d f: 4 ; P< \\
0.0001)\end{array}$ & $0.08 \pm 0.28 \mathrm{~b}$ & $0.00 \pm 0.00 \mathrm{~b}$ & $0.00 \pm 0.00 \mathrm{~b}$ & $0.58 \pm 0.51 \mathrm{a}$ & $0.83 \pm 0.71 \mathrm{a}$ \\
\hline & A. decempunctata/beating $(F=1.95 ; d f: 4 ; P=0.1180)$ & $0.41 \pm 0.99 b$ & $0.83 \pm 1.19 \mathrm{ab}$ & $0.83 \pm 0.93 \mathrm{ab}$ & $1.58 \pm 1.16 \mathrm{a}$ & $1.16 \pm 1.11 \mathrm{ab}$ \\
\hline & Coccinellidae/beating $(F=4.05 ; d f: 4 ; P=0.0068)$ & $0.5 \pm 1.00 \mathrm{~b}$ & $0.83 \pm 1.19 b$ & $0.83 \pm 0.93 b$ & $2.16 \pm 1.40 \mathrm{a}$ & $2 \pm 1.59 \mathrm{a}$ \\
\hline & Coccinellidae/shoots $(F=17.84 ; d f: 4 ; P<0.0001)$ & $0 \pm 0.00 \mathrm{~d}$ & $1.58 \pm 1.97 \mathrm{bc}$ & $1.17 \pm 1.19 \mathrm{c}$ & $4 \pm 2.13 \mathrm{a}$ & $15.9 \pm 14.14 \mathrm{ab}$ \\
\hline & Spiders/beating $(F=1.23 ; d f: 4 ; P=0.3130)$ & $0.66 \pm 0.89 \mathrm{a}$ & $1.75 \pm 1.42 \mathrm{a}$ & $0.91 \pm 1.56 \mathrm{a}$ & $1.41 \pm 2.11 \mathrm{a}$ & $2 \pm 2.41 \mathrm{a}$ \\
\hline & Parasitism & $0.00 \pm 0.00 \mathrm{a}$ & $0.00 \pm 0.00 \mathrm{a}$ & $0.00 \pm 0.00 \mathrm{a}$ & $0.00 \pm 0.00 \mathrm{a}$ & $0.00 \pm 0.00 \mathrm{a}$ \\
\hline \multirow[t]{9}{*}{14 dat } & Hymenoptera/sticky trap $(F=26.75 d f: 4 ; P=0.0001)$ & $0.00 \pm 0.00 \mathrm{c}$ & $0.00 \pm 0.00 \mathrm{c}$ & $0.66 \pm 0.57 b$ & $2 \pm 1.00 \mathrm{a}$ & $2.66 \pm 0.57 \mathrm{a}$ \\
\hline & C. carnea $/$ beating $(F=1.16 ; d f: 4 ; P=0.3423)$ & $0.33 \pm 0.77 \mathrm{a}$ & $0.41 \pm 0.79 \mathrm{a}$ & $0.00 \pm 0.00 \mathrm{a}$ & $0.16 \pm 0.38 \mathrm{a}$ & $0.41 \pm 0.66 \mathrm{a}$ \\
\hline & E. balteatus/observation & $0.00 \pm 0.00 \mathrm{a}$ & $0.00 \pm 0.00 \mathrm{a}$ & $0.00 \pm 0.00 \mathrm{a}$ & $0.00 \pm 0.00 \mathrm{a}$ & $0.00 \pm 0.00 \mathrm{a}$ \\
\hline & C. septempunctata/beating & $0.00 \pm 0.00 \mathrm{a}$ & $0.00 \pm 0.00 \mathrm{a}$ & $0.00 \pm 0.00 \mathrm{a}$ & $0.00 \pm 0.00 \mathrm{a}$ & $0.00 \pm 0.00 \mathrm{a}$ \\
\hline & A. decempunctata/beating $(F=0.76 ; d f: 4 ; P=0.5588)$ & $0.75 \pm 1.28 \mathrm{a}$ & $1 \pm 1.59 \mathrm{a}$ & $1.08 \pm 2.31 \mathrm{a}$ & $0.16 \pm 0.38 \mathrm{a}$ & $0.75 \pm 0.86 \mathrm{a}$ \\
\hline & Coccinellidae/beating $(F=0.76 ; d f: 4 ; P=0.5588)$ & $0.75 \pm 1.28 \mathrm{a}$ & $1 \pm 1.59 \mathrm{a}$ & $1.08 \pm 2.31 \mathrm{a}$ & $0.16 \pm 0.38 \mathrm{a}$ & $0.75 \pm 0.86 \mathrm{a}$ \\
\hline & Coccinellidae/shoots $(F=5.65 ; d f: 4 ; P<0.0009)$ & $0.00 \pm 0.00 \mathrm{~b}$ & $0.08 \pm 0.28 b$ & $0.00 \pm 0.00 \mathrm{~b}$ & $2.33 \pm 4.39 \mathrm{a}$ & $0.42 \pm 0.79 b$ \\
\hline & Spiders/frappage $(F=4.65 ; d f: 4 ; P: 0.0031)$ & $1 \pm 1.28 \mathrm{ab}$ & $1.83 \pm 1.59 \mathrm{a}$ & $0.33 \pm 1.15 b$ & $1.91 \pm 1.56 \mathrm{a}$ & $1.91 \pm 1.44 \mathrm{a}$ \\
\hline & Parasitism & $0.00 \pm 0.00 \mathrm{a}$ & $0.00 \pm 0.00 \mathrm{a}$ & $0.00 \pm 0.00 \mathrm{a}$ & $0.00 \pm 0.00 \mathrm{a}$ & $0.00 \pm 0.00 \mathrm{a}$ \\
\hline \multirow[t]{9}{*}{21 dat } & Hymenoptera/sticky trap $(F=13.01 d f: 4 ; P=0.0014)$ & $0 \pm 0.00 \mathrm{~b}$ & $0 \pm 0.00 \mathrm{~b}$ & $0 \pm 0.00 \mathrm{~b}$ & $2 \pm 1.00 \mathrm{a}$ & $2.33 \pm 1.52 \mathrm{a}$ \\
\hline & $C$. carnea/beating $(F=7.20 ; d f: 4 ; P=0.0001)$ & $0.41 \pm 0.66 \mathrm{~b}$ & $0.16 \pm 0.38 b$ & $0.66 \pm 0.88 b$ & $0.91 \pm 0.99 b$ & $2.5 \pm 3.06 \mathrm{a}$ \\
\hline & E. balteatus/observation $(F=2.00 ; d f: 4 ; P=0.1107)$ & $0.00 \pm 0.00 \mathrm{~b}$ & $0.00 \pm 0.00 \mathrm{~b}$ & $0.00 \pm 0.00 \mathrm{~b}$ & $0.25 \pm 0.45 \mathrm{a}$ & $0.17 \pm 0.39 \mathrm{ab}$ \\
\hline & C. septempunctata/beating $(F=3.16 ; d f: 4 ; P=0.0226)$ & $0.00 \pm 0.00 \mathrm{~b}$ & $0.25 \pm 0.45 \mathrm{ab}$ & $0.00 \pm 0.00 \mathrm{~b}$ & $0.42 \pm 0.66 \mathrm{a}$ & $0.5 \pm 0.52 \mathrm{a}$ \\
\hline & A. decempunctata/beating $(F=5.79 ; d f: 4 ; P=0.0008)$ & $0.5 \pm 0.79 b$ & $0.5 \pm 0.79 b$ & $0.5 \pm 1.24 \mathrm{~b}$ & $0.66 \pm 0.65 b$ & $1.66 \pm 0.65 \mathrm{a}$ \\
\hline & Coccinellidae/beating $(F=6.31 ; d f: 4 ; P=0.0004)$ & $0.5 \pm 0.79 b$ & $0.75 \pm 1.13 b$ & $0.5 \pm 1.24 \mathrm{~b}$ & $1.08 \pm 1.16 \mathrm{~b}$ & $2.16 \pm 0.71 \mathrm{a}$ \\
\hline & Coccinellidae/shoots & $0.00 \pm 0.00 \mathrm{a}$ & $0.00 \pm 0.00 \mathrm{a}$ & $0.00 \pm 0.00 \mathrm{a}$ & $0.00 \pm 0.00 \mathrm{a}$ & $0.00 \pm 0.00 \mathrm{a}$ \\
\hline & Spiders/beating $(F=2.59 ; d f: 4 ; P=0.0493)$ & $0.25 \pm 0.45 b$ & $1.25 \pm 0.87 \mathrm{a}$ & $0.83 \pm 0.72 \mathrm{ab}$ & $0.75 \pm 0.87 \mathrm{ab}$ & $0.75 \pm 0.75 \mathrm{ab}$ \\
\hline & Parasitism & $0.00 \pm 0.00 \mathrm{a}$ & $0.00 \pm 0.00 \mathrm{a}$ & $0.00 \pm 0.00 \mathrm{a}$ & $0.00 \pm 0.00 \mathrm{a}$ & $0.00 \pm 0.00 \mathrm{a}$ \\
\hline
\end{tabular}

Within each row, values followed by a common letter do not differ significantly ( $P<5 \%$; LSD test)

beneficial species, especially Hymenoptera (Cerillo et al. 2005; Krespi et al. 1991; Schuster 1994). The Environment Protection Agency (EPA), the European Chemical Classification (ECC) and the World
Health Organization (WHO) classify methomyl as very toxic and hazardous (Mohamed 2009). Imidacloprid is known for its side effects on natural enemies such as coccinellids (Smith \& Krischik 1999), Hymenoptera: 
Table 9 Average abundance of natural enemies (number/trap, observation, beating or shoot, $\pm \mathrm{SE})$ and rate of parasitism $(\% \pm \mathrm{SE})$ on a young citrus plantation during 2010. A one-way ANOVA was used to compare natural enemies abundance and rate of parasitism.
C. carnea; E. balteatus; C. septempunctata; A. decempunctata; Rodolia cardinalis (Mulsant); Stethorus punctillum (Weise) and Scymnus sp (Coleoptera: Coccinellidae) [dat=days after treatment]

\begin{tabular}{|c|c|c|c|c|c|c|}
\hline & & Imidacloprid & Soap & Kaolin & Adalia/d2 & Control \\
\hline \multirow[t]{12}{*}{5 dat } & Hymenoptera/sticky trap $(F=0.05 d f: 4 ; P=0.9936)$ & $0.33 \pm 0.57 \mathrm{a}$ & $0.66 \pm 1.15 \mathrm{a}$ & $0.66 \pm 1.15 \mathrm{a}$ & $0.66 \pm 1.15 \mathrm{a}$ & $0.66 \pm 0.57 \mathrm{a}$ \\
\hline & C. carnea $/$ beating $(F=5.10 ; d f: 4 ; P=0.0018)$ & $0.00 \pm 0.00 \mathrm{c}$ & $0.08 \pm 0.28 \mathrm{bc}$ & $0.41 \pm 0.51 \mathrm{ab}$ & $0.66 \pm 0.79 \mathrm{ab}$ & $1 \pm 0.62 \mathrm{a}$ \\
\hline & E. balteatus/observation & nr* & $\mathrm{nr}$ & $\mathrm{nr}$ & $\mathrm{nr}$ & $\mathrm{nr}$ \\
\hline & C. septempunctata/beating $(F=1.92 ; d f: 4 ; P=0.01242)$ & $0.16 \pm 0.57 \mathrm{~b}$ & $0.75 \pm 0.96 \mathrm{ab}$ & $0.83 \pm 1.19 \mathrm{ab}$ & $0.75 \pm 1.13 \mathrm{ab}$ & $1.33 \pm 2.14 \mathrm{a}$ \\
\hline & A. decempunctata/beating $(F=3.03 ; d f: 4 ; P=0.0271)$ & $0.33 \pm 0.49 b$ & $1.08 \pm 0.99 \mathrm{ab}$ & $2.58 \pm 3.47 \mathrm{a}$ & $1.58 \pm 1.78 \mathrm{ab}$ & $2.25 \pm 2.17 \mathrm{a}$ \\
\hline & S. punctillum/beating & $0.00 \pm 0.00 \mathrm{a}$ & $0.00 \pm 0.00 \mathrm{a}$ & $0.00 \pm 0.00 \mathrm{a}$ & $0.00 \pm 0.00 \mathrm{a}$ & $0.00 \pm 0.00 \mathrm{a}$ \\
\hline & R. cardinalis/beating $(F=1.33 ; d f: 4 ; P=0.2723)$ & $0.00 \pm 0.00 \mathrm{a}$ & $0.00 \pm 0.00 \mathrm{a}$ & $0.08 \pm 0.28 \mathrm{a}$ & $0.16 \pm 0.38 \mathrm{a}$ & $0.00 \pm 0.00 \mathrm{a}$ \\
\hline & Scymnus sp. $(F=1.03 ; d f: 4 ; P=0.4036)$ & $0.16 \pm 0.39 \mathrm{a}$ & $0.33 \pm 0.65 \mathrm{a}$ & $0.58 \pm 1.08 \mathrm{a}$ & $0.16 \pm 0.39 \mathrm{a}$ & $0.58 \pm 0.9 \mathrm{a}$ \\
\hline & Coccinellidae/beating $(F=5.45 ; d f: 4 ; P=0.0012)$ & $0.66 \pm 1.07 \mathrm{c}$ & $2 \pm 1.27 \mathrm{~b}$ & $4.08 \pm 4.69 \mathrm{ab}$ & $2.66 \pm 2.10 \mathrm{ab}$ & $4.16 \pm 3.97 \mathrm{a}$ \\
\hline & Coccinellidae/shoots $F=1.75 ; d f: 4 ; P=01552)$ & $0.25 \pm 0.26 \mathrm{a}$ & $0.33 \pm 0.77 \mathrm{a}$ & $0.58 \pm 1.50 \mathrm{a}$ & $1.33 \pm 1.43 \mathrm{a}$ & $0.75 \pm 1.21 \mathrm{a}$ \\
\hline & Spiders/beating $(F=3.75 ; d f: 4 ; P=0.0103)$ & $0.5 \pm 0.52 \mathrm{c}$ & $0.83 \pm 0.83 \mathrm{bc}$ & $1.16 \pm 0.94 b c$ & $2.41 \pm 1.83 \mathrm{a}$ & $1.83 \pm 1.85 \mathrm{ab}$ \\
\hline & Parasitism $(F=0.88 ; d f: 4 ; P=0.4839)$ & $0.52 \pm 1.80 \mathrm{a}$ & $25.44 \pm 86.46 a$ & $3.13 \pm 5.89 a$ & $1.25 \pm 1.70 \mathrm{a}$ & $0.83 \pm 0.94 \mathrm{a}$ \\
\hline \multirow[t]{12}{*}{7 dat } & Hymenoptera/sticky trap $(F=0.80 d f: 4 ; P=0.5553)$ & $0.00 \pm 0.00 \mathrm{a}$ & $1.33 \pm 2.30 \mathrm{a}$ & $0.00 \pm 0.00 \mathrm{a}$ & $2 \pm 1.73 \mathrm{a}$ & $1.33 \pm 2.30 \mathrm{a}$ \\
\hline & C. carnea/beating $(F=0.19 ; d f: 4 ; P=0.9415)$ & $0.33 \pm 0.49 \mathrm{a}$ & $0.58 \pm 1.44 \mathrm{a}$ & $0.33 \pm 0.49 \mathrm{a}$ & $0.41 \pm 0.79 \mathrm{a}$ & $0.25 \pm 0.62 \mathrm{a}$ \\
\hline & E. balteatus/observation & $\mathrm{nr}$ & $\mathrm{nr}$ & $\mathrm{nr}$ & $\mathrm{nr}$ & $\mathrm{nr}$ \\
\hline & C. septempunctata/beating $(F=1,18 ; d f: 4 ; P=0.3328)$ & $0.33 \pm 0.88 \mathrm{a}$ & $0.008 \pm 0.28 \mathrm{a}$ & $0.33 \pm 0.88 \mathrm{a}$ & $0.58 \pm 0.90 \mathrm{a}$ & $0.58 \pm 0.79 \mathrm{a}$ \\
\hline & A. decempunctata/beating $(F=0.88 ; d f: 4 ; P=0.4819)$ & $0.25 \pm 0.62 \mathrm{a}$ & $1.33 \pm 2.06 \mathrm{a}$ & $1.16 \pm 2.03 \mathrm{a}$ & $0.83 \pm 1.26 \mathrm{a}$ & $1 \pm 2.13 \mathrm{a}$ \\
\hline & S. punctillum/beating & $0.00 \pm 0.00 \mathrm{a}$ & $0.00 \pm 0.00 \mathrm{a}$ & $0.00 \pm 0.00 \mathrm{a}$ & $0.00 \pm 0.00 \mathrm{a}$ & $0.00 \pm 0.00 \mathrm{a}$ \\
\hline & $R$. cardinalis/beating $(F=0.79 ; d f: 4 ; P=0.5405)$ & $0.00 \pm 0.00 \mathrm{a}$ & $0.16 \pm 0.57 \mathrm{a}$ & $0.00 \pm 0.00 \mathrm{a}$ & $0.00 \pm 0.00 \mathrm{a}$ & $0.08 \pm 0.28 \mathrm{a}$ \\
\hline & Scymnus sp./ beating $(F=2.06 ; d f: 4 ; P=0.1020)$ & $0.00 \pm 0.00 \mathrm{a}$ & $0.41 \pm 0.90 \mathrm{a}$ & $0.00 \pm 0.00 \mathrm{a}$ & $0.58 \pm 0.99 \mathrm{a}$ & $0.08 \pm 0.28 \mathrm{a}$ \\
\hline & Coccinellidae/beating $(F=1.40 ; d f: 4 ; P=0.2497)$ & $0.58 \pm 0.99 b$ & $2 \pm 2.95 \mathrm{ab}$ & $1.5 \pm 2.27 \mathrm{ab}$ & $2 \pm 1.75 \mathrm{a}$ & $1.75 \pm 2.30 \mathrm{ab}$ \\
\hline & Coccinellidae/shoots $(F=1.79 ; d f: 4 ; P=0.1479)$ & $0.167 \pm 0.38 \mathrm{a}$ & $0.75 \pm 1.35 \mathrm{a}$ & $1.25 \pm 1.42 \mathrm{a}$ & $1 \pm 1.12 \mathrm{a}$ & $1.17 \pm 1.80 \mathrm{a}$ \\
\hline & Spiders/beating $(F=0.37 ; d f: 4 ; P=0.8260)$ & $0.83 \pm 1.11 \mathrm{a}$ & $1.33 \pm 1.83 \mathrm{a}$ & $0.75 \pm 1.14 \mathrm{a}$ & $1.16 \pm 1.53 \mathrm{a}$ & $0.83 \pm 1.34 \mathrm{a}$ \\
\hline & Parasitism $(F=2.64 ; d f: 4 ; P=0.0457)$ & $0.00 \pm 0.00 \mathrm{~b}$ & $0.25 \pm 0.47 \mathrm{ab}$ & $0.33 \pm 0.70 \mathrm{ab}$ & $0.00 \pm 0.00 \mathrm{~b}$ & $0.61 \pm 1.11 \mathrm{a}$ \\
\hline \multirow[t]{12}{*}{14 dat } & Hymenoptera/sticky trap $(F=2.44 d f: 4 ; P=0.1319)$ & $0.00 \pm 0.00 \mathrm{a}$ & $2.0 \pm 0.00 \mathrm{a}$ & $0.00 \pm 0.00 \mathrm{a}$ & $0.33 \pm 0.57 \mathrm{a}$ & $1.33 \pm 2.30 \mathrm{a}$ \\
\hline & C. carnea $/$ beating $(F=1.1 ; d f: 4 ; P=0.3694)$ & $0.00 \pm 0.00 \mathrm{a}$ & $0.16 \pm 0.38 \mathrm{a}$ & $0.25 \pm 0.62 \mathrm{a}$ & $0.00 \pm 0.00 \mathrm{a}$ & $0.25 \pm 0.62 \mathrm{a}$ \\
\hline & E.balteatus/observation & $\mathrm{nr}$ & $\mathrm{nr}$ & $\mathrm{nr}$ & $\mathrm{nr}$ & $\mathrm{nr}$ \\
\hline & C. septempunctata/beating $(F=0.75 ; d f: 4 ; P=0.5632)$ & $0.25 \pm 0.99 \mathrm{a}$ & $0.16 \pm 0.38 \mathrm{a}$ & $0.25 \pm 0.45 \mathrm{a}$ & $0.00 \pm 0.00 \mathrm{a}$ & $0.66 \pm 2.01 \mathrm{a}$ \\
\hline & A. decempunctata/beating $(F=1.61 ; d f: 4 ; P=0.1894)$ & $0.08 \pm 0.28 \mathrm{a}$ & $0.75 \pm 1.35 \mathrm{a}$ & $0.33 \pm 1.15 \mathrm{a}$ & $0.16 \pm 0.57 \mathrm{a}$ & $0.08 \pm 0.28 \mathrm{a}$ \\
\hline & S. punctillum/beating & $0.00 \pm 0.00 \mathrm{a}$ & $0.00 \pm 0.00 \mathrm{a}$ & $0.00 \pm 0.00 \mathrm{a}$ & $0.00 \pm 0.00 \mathrm{a}$ & $0.00 \pm 0.00 \mathrm{a}$ \\
\hline & R. cardinalis/beating & $0.00 \pm 0.00 \mathrm{a}$ & $0.00 \pm 0.00 \mathrm{a}$ & $0.00 \pm 0.00 \mathrm{a}$ & $0.00 \pm 0.00 \mathrm{a}$ & $0.00 \pm 0.00 \mathrm{a}$ \\
\hline & Scymnus sp./beating $(F=0.5 ; d f: 4 ; P=0.7358)$ & $0.00 \pm 0.00 \mathrm{a}$ & $0.83 \pm 0.28 \mathrm{a}$ & $0.83 \pm 0.28 \mathrm{a}$ & $0.83 \pm 0.28 \mathrm{a}$ & $0.00 \pm 0.00 \mathrm{a}$ \\
\hline & Coccinellidae/beating $(F=0.65 ; d f: 4 ; P=0.6305)$ & $0.5 \pm 1.00 \mathrm{a}$ & $1 \pm 1.59 \mathrm{a}$ & $0.66 \pm 1.15 \mathrm{a}$ & $0.25 \pm 0.86 \mathrm{a}$ & $0.75 \pm 2.00 \mathrm{a}$ \\
\hline & Coccinellidae/shoots $(F=1.80 ; d f: 4 ; P=0.1458)$ & $0.16 \pm 0.38 \mathrm{a}$ & $0.5 \pm 0.90 \mathrm{a}$ & $0.00 \pm 0.00 \mathrm{a}$ & $0.08 \pm 0.28 \mathrm{a}$ & $0.17 \pm 0.38 \mathrm{a}$ \\
\hline & Spiders/beating $(F=0.84 ; d f: 4 ; P=0.5079)$ & $0.25 \pm 0.62 \mathrm{a}$ & $0.66 \pm 1.07 \mathrm{a}$ & $1.08 \pm 1.16 \mathrm{a}$ & $0.83 \pm 1.64 \mathrm{a}$ & $0.58 \pm 0.79 \mathrm{a}$ \\
\hline & Parasitism & $0.00 \pm 0.00 \mathrm{a}$ & $0.33 \pm 1.15 \mathrm{a}$ & $0.00 \pm 0.00 \mathrm{a}$ & $0.00 \pm 0.00 \mathrm{a}$ & $0.00 \pm 0.00 \mathrm{a}$ \\
\hline \multirow[t]{6}{*}{21 dat } & Hymenoptera/sticky trap $(F=1.91 d f: 4 ; P=0.2019)$ & $0.00 \pm 0.00 \mathrm{a}$ & $0.00 \pm 0.00 \mathrm{a}$ & $0.00 \pm 0.00 \mathrm{a}$ & $1 \pm 1.00 \mathrm{a}$ & $0.66 \pm 1.15 \mathrm{a}$ \\
\hline & C. carnea/beating $(F=3.59 ; d f: 4 ; P=0.0127)$ & $0.00 \pm 0.00 \mathrm{~b}$ & $0.00 \pm 0.00 \mathrm{~b}$ & $0.00 \pm 0.00 \mathrm{~b}$ & $0.08 \pm 0.28 b$ & $0.41 \pm 0.66 \mathrm{a}$ \\
\hline & E. balteatus/observation & $\mathrm{nr}$ & $\mathrm{nr}$ & $\mathrm{nr}$ & $\mathrm{nr}$ & $\mathrm{nr}$ \\
\hline & C. septempunctata/beating ( $F=2.46 ; d f: 4 ; P=0.0591)$ & $0.00 \pm 0.00 \mathrm{~b}$ & $0.5 \pm 0.90 \mathrm{a}$ & $0.33 \pm 0.77 \mathrm{ab}$ & $0.00 \pm 0.00 \mathrm{~b}$ & $0.16 \pm 0.38 \mathrm{ab}$ \\
\hline & A. decempunctata/beating $(F=0.12 ; d f: 4 ; P=0.9747)$ & $0.25 \pm 0.86 \mathrm{a}$ & $0.16 \pm 0.38 \mathrm{a}$ & $0.08 \pm 0.28 \mathrm{a}$ & $0.16 \pm 0.38 \mathrm{a}$ & $0.16 \pm 0.38 \mathrm{a}$ \\
\hline & S. punctillum/beating $(F=0.32 ; d f: 4 ; P=0.8622)$ & $0.16 \pm 0.57 \mathrm{a}$ & $0.00 \pm 0.00 \mathrm{a}$ & $0.08 \pm 0.28 \mathrm{a}$ & $0.08 \pm 0.28 \mathrm{a}$ & $0.16 \pm 0.57 \mathrm{a}$ \\
\hline
\end{tabular}


Table 9 (continued)

\begin{tabular}{|c|c|c|c|c|c|}
\hline & Imidacloprid & Soap & Kaolin & Adalia/d2 & Control \\
\hline R. cardinalis/beating & $0.00 \pm 0.00 \mathrm{a}$ & $0.00 \pm 0.00 \mathrm{a}$ & $0.00 \pm 0.00 \mathrm{a}$ & $0.00 \pm 0.00 \mathrm{a}$ & $0.00 \pm 0.00 \mathrm{a}$ \\
\hline Scymnus sp./beating ( $F=0.75 ; d f: 4 ; P=0.5632)$ & $0.00 \pm 0.00 \mathrm{a}$ & $0.08 \pm 0.28 \mathrm{a}$ & $0.00 \pm 0.00 \mathrm{a}$ & $0.00 \pm 0.00 \mathrm{a}$ & $0.08 \pm 0.28 \mathrm{a}$ \\
\hline Coccinellidae/beating $(F=0 ; 68 ; d f: 4 ; P=0,6123)$ & $0.41 \pm 0.99 \mathrm{a}$ & $0.75 \pm 1.21 \mathrm{a}$ & $0.5 \pm 0.79 \mathrm{a}$ & $0.25 \pm 0.62 \mathrm{a}$ & $0.58 \pm 0.79 \mathrm{a}$ \\
\hline Coccinellidae/shoots $(F=0.50 ; d f: 4 ; P=0.7381)$ & $0.00 \pm 0.00 \mathrm{a}$ & $0.17 \pm 0.57 \mathrm{a}$ & $0.17 \pm 0.38 \mathrm{a}$ & $0.17 \pm 0.38 \mathrm{a}$ & $0.08 \pm 0.28 \mathrm{a}$ \\
\hline Spiders/beating $(F=0.29 ; d f: 4 ; P=0.8817)$ & $0.58 \pm 0.79 \mathrm{a}$ & $0.66 \pm 1.22 \mathrm{a}$ & $0.25 \pm 0.78 \mathrm{a}$ & $0.58 \pm 1.08 \mathrm{a}$ & $0.66 \pm 1.30 \mathrm{a}$ \\
\hline Parasitism & $0.00 \pm 0.00 \mathrm{a}$ & $0.00 \pm 0.00 \mathrm{a}$ & $0.00 \pm 0.00 \mathrm{a}$ & $0.00 \pm 0.00 \mathrm{a}$ & $0.00 \pm 0.00 \mathrm{a}$ \\
\hline
\end{tabular}

Within each row, values followed by a common letter do not differ significantly $\left(P<5 \%\right.$; LSD test). ${ }^{*} n r$ not realized

Apidae, in the laboratory (Schmuck et al. 2001); Coccinellidae on peach groves (Karagounis et al. 2006; Kourdoumbalos et al. 2006); the Neuroptera Hemerobiidae on lettuce (Cole and Horne 2006); and predatory beetles on okra (Solangi \& Lohar 2007); and some pollinator insects of wild flowers (Mommaerts et al. 2010).

In a field trial, insecticidal soap and kaolin foliar spray reduced aphid density for one week. In contrast, they do not seem very effective in reducing citrus shoot infestations. In a previous study, three products allowed in organic farming (kaolin, mineral oil and insecticidal soap) were applied for the control of $M$. persicae in a peach orchard (Karagounis et al. 2006). According to this study, all products showed good control in the first year, but in the next year they were less effective. However, a study examining the effects of kaolin particle film treatments on some pests in apple cv. 'Golden Delicious' orchards in Europe showed that there was no effect on the number of colonies of rosy leaf-curling aphid Dysaphis devecta Walker (Marko et al. 2008). According to that study the level of infestation of rosy apple aphid Dysaphis plantaginea Passerini and the woolly apple aphid Eriosoma lanigerum Hausmann increased in the kaolin-treated plots. Under our conditions, aphid density and citrus shoot infestation were reduced one week after A. decempunctata release. Ladybirds were effective during this week, probably because the $A$. decempunctata adults released had at first a great capacity for search and predation, but after the first week the predation was low. Two possible hypotheses can explain this; first, the low number of A. decempunctata adults released (both for $\mathrm{d} 1$ and $\mathrm{d} 4$ ), and second the presence of ants in this citrus orchard after this first week influenced coccinellids predation of aphids.
Under citrus field conditions, methomyl, imidacloprid and insecticidal soap also showed lower densities of natural enemies compared with kaolin treatment and $A$. decempunctata release. The density of coccinellids was higher in adalia/d1 and adalia/d2 plots for one week. However, in the second year, the mean density of each species taken separately was similar for all treatments, except for imidacloprid, which was much lower. On apples, spraying kaolin once a week for 4 weeks against Choristoneura rosaceana Harris (Lepidoptera: Tortricidae), altered the composition of generalist predators and reduced the abundance of some families such as the coccinellids (Sackett et al. 2005). In olive groves, kaolin revealed during 3 years a significant deleterious effect on the natural enemy arthropod community such as Scymnus mediterraneus Iablokoff-Khnzorian, Stethorus punctillum Weise and Hyperaspis reppensis Herbst (Pascual et al. 2010). However, the previous study on $M$. persicae in a peach orchard showed that insecticidal soap and kaolin had little or no adverse effects on Coccinellidae (Karagounis et al. 2006; Kourdoumbalos et al. 2006). In contrast, insecticidal soaps application may be compatible with biological control of the Asian citrus psyllid (ACP), Diaphorina citri Kuwayama (Hemiptera: Psyllidae), by adult coccinellids like Cycloneda sanguinea (L.) (Coleoptera: Coccinellidae), but not the parasitoid Tamarixia radiata (Waterston) (Hymenoptera: Eulophidae) (Hall \& Richardson 2013).

Chrysopidae species are known as generalist predators that greatly contribute to the natural control of pest species in citrus orchards such as aphids, citrus leafminer and whiteflies (Michaud 1999, 2001). In our study, $C$. carnea density was high during the first week for dalia/d1 and untreated control treatments during 2009 and for adalia/d2, kaolin and untreated control treatments during 2010. However, in apple groves, 
despite the fact that the aphid prey supply was substantially higher, Chrysopidae adults did not aggregate in the kaolin-treated plots (Marko et al. 2008). In olive fields, the number of Chrysopidae adults was lower in the kaolin plot than in the untreated control plot over the 3 years of study (Pascual et al. 2010). The spiders Araneidae, Philodromidae and Salticidae were the most numerous family, with predation as their main behavior. During the 2 years, spider densities were similar for all treatments, although slightly higher in adalia/d1 and adalia/d2 treatments. On apples, spraying kaolin altered and reduced the abundance of the spiders Salticidae and Philodromidae (Marko et al. 2008; Sackett et al. 2005). In olive groves, the family Philodromidae was the most vulnerable to kaolin spraying (Pascual et al. 2010). In our field trials, hoverfly E. balteatus densities were similar for all treatments, although their density was relatively high in the plots where $A$. decempunctata was released and in the untreated control. In apple, kaolin spraying reduced the abundance of polyphagous predators like predaceous Heteroptera and the red velvet mite Allothrombium fuliginosum Hermann (Marko et al. 2008). Except for a maximum of $25.44 \%$ noted for the insecticidal soap treatment, the parasitism seemed to be similar for all treatments. However, the hymenoptera recorded in the sticky traps were more numerous in the plots where $A$. decempunctata were released and the untreated plot.

It appears that a single foliar application with kaolin, insecticidal soap and both densities of $A$. decempunctata release is not sufficient to control aphids in young citrus groves. A single foliar spraying with kaolin and insecticidal soap did not prove to be a suitable solution to control aphids. However, frequent releases with higher doses than those experimented with of A.decempunctata, are considered as a promising and potential alternative method to control aphids. The same holds true for Scymnus subvillosus Goeze and C. septempunctata, species very abundant and with low dispersal behavior in most citrus orchards in Morocco (M. C. Smaili, personal observation).

This trial provided information about which safe natural products (insecticidal soap and kaolin) merit consideration and also about the possibility to incorporate indigenous natural enemies such as $A$. decempunctata into an integrated management strategy for controlling aphids in young citrus groves.
Acknowledgments This work was funded by the National Agricultural Research Institute (PRMT 2009-20012, INRA-CRRA, Kenitra, Morocco). The authors thank Prof. Abdeljalil Bakri (Insect Control, Marrakech, Morocco) and Prof. Luca Corelli Grappadelli (Department of Fruit Trees and Woody Plant Sciences, University of Bologna, Italy) for their help in preparing the manuscript and improving the English. We thank Dr. Susan Halbert (Florida Department of Agriculture and Consumer Services, Division of Plant Industry, USA) and anonymous referees for useful comments on earlier drafts of the manuscript. We thank Mohamed Zaghloul, Dieudonne Shyrambere and Hassan Boudraim for their technical assistance in the field. Thanks are also extended to Dr. Benaouda Hassan, Dr. Benyahia Hamid and Mr. Tahiri Sidi Mohamed (INRA, CRRA, Kenitra, Morocco) for making this research possible.

Open Access This article is distributed under the terms of the Creative Commons Attribution License which permits any use, distribution, and reproduction in any medium, provided the original author(s) and the source are credited.

\section{References}

Abbott, W. S. (1925). A method of computing the effectiveness of an insecticide. Journal of Economic Entomology, 18, 265-267.

AMPP. (2013). Index phytosanitaire Maroc. Rabat, Maroc: Association Marocaine de Protection des Plantes Edition.

Braham, M., Pasqualini, E., \& Ncira, N. (2007). Efficacy of kaolin, spinosad and malathion against Ceratitis capitata in citrus orchards. Bulletin of Insectology, 60, 39-47.

Cerrillo, I., Granada, A., Lopez-Espinosa, M. J., Olmosa, B., Jimeneza, M., Cano, A., et al. (2005). Endosulfan and its metabolites in fertile women, placenta, cord blood, and human milk. Environmental Research, 98, 233-239.

Cock, M. J. W., Van Lenteren, J. C., Brodeur, J., Barratt, B. I. P., Bigler, F., Bolckmans, K., et al. (2009). The use and exchange of biological control agents for food and agriculture. Background Study Paper $N^{\circ} 47$. FAO, Rome Italy: Commission on Genetic Resources for Food and Agriculture.

Cole, P. G., \& Horne, P. A. (2006). The impact of aphicide drenches on Micromus tasmaniae (Walker) (Neuroptera: Hemerobiidae) and the implications for pest control in lettuce crops. Australian Journal of Entomology, 45, 244-248.

Crowder, D. W. (2007). Impact of release rates on the effectiveness of augmentative biological control agents. Journal of Insect Sciences, 7, 15.

EPPO. (2004). Good plant protection practice: citrus. Bulletin OEPP/EPPO, 34, 43-56.

EPPO. (2006). Diagnostic Toxoptera citricidus. Bulletin OEPP/ EPPO, 36, 451-456.

Hall, D. G., \& Richardson, M. L. (2013). Toxicity of insecticidal soaps to the Asian citrus psyllid and two of its natural enemies. Journal of Applied Entomology, 137, 347-354.

Henderson, C. F., \& Tilton, E. W. (1955). Tests with acaricides against the brown wheat mite. Journal of Economic Entomology, 48, 157-161. 
Ilharco, F. A., \& Sousa-Silva, C. R. (2009). Toxoptera citricidus (Kirkaldy, 1907) (Homoptera, Aphidoidea), the tropical citrus aphid in continental Portugal. Citrus Tristeza Virus and Toxoptera citricidus. a serious threat to the Mediterranean citrus industry. Options Méditerranéennes, 65, 53-58.

Iperti, G. (1999). Biodiversity of predaceous coccinellidae in relation to bioindication and economic importance. Agriculture, Ecosystems and Environment, 74, 323-342.

Jaastad, G., Røen, D., Hovland, B., \& Opedal, O. (2006). Kaolin as a possible treatment against lepidopteran larvae and mites in organic fruit production. Proceedings Ecofruit, 12th International Conference on Cultivation Technique and Phytopathological Problems in Organic Fruit-Growing (Weinsberg, Germany, pp. 31-35).

Karagounis, C., Kourdoumbalos, A. K., Margaritopoulos, J. T., Nanos, G. D., \& Tsitsipis, J. A. (2006). Organic farmingcompatible insecticides against the aphid Myzus persicae (Sulzer) in peach orchards. Journal of Applied Entomology, 130, 150-154.

Kourdoumbalos, A. K., Margaritopoloulos, J. T., Nanos, G. D., \& Tsitsipis, J. A. (2006). Alternative aphid control methods for peach production. Journal of Fruit Ornamental Plant Research, 14, 181-189.

Krespi, L., Rabasse, J. M., Dedryver, C. A., \& Nenon, J. P. (1991). Effect of three insecticides on the life cycle of Aphidius uzbekistanicus Luz. (Hym., Aphidiidae). Journal of Applied Entomology, 111, 113-119.

Larentzaki, E., Shelton, A. M., \& Plate, J. (2008). Effect of kaolin particle film on Thrips tabaci (Thysanoptera:Thripidae), oviposition, feeding and development on onions: a lab and field case study. Crop Protection, 27, 727-734.

MAPM. (2008). Contrat programme 2009-2018 entre le gouvernement et la profession agrumicole représentée par l'association des producteurs d'agrumes du Maroc et les groupes exportateurs Maroc Fruit Board et Fresh Fruit relatif à la mise à niveau de la filière agrumicole. Rapport du Ministère de l'Agriculture et de la Pèche Maritime, Rabat, Maroc.

Marko, V., Blommers, L. H. M., Bogya, S., \& Helsen, H. (2008). Kaolin particle films suppress many apple pests, disrupt natural enemies and promote woolly apple aphid. Journal of Applied Entomology, 132, 26-35.

Mazih, A. (2011). Citrus IPM in Morocco: Current status. In Proceedings of Meeting of Working Group "Integrated Control in Citrus Fruit Crops" (2010, Agadir, Morocco). IOBC/WPRS Bulletin, 62, 266 (Abstr.).

Mazor, M., \& Erez, A. (2004). Processed kaolin protects fruits from Mediterranean fruit fly infestations. Crop Protection, $23,47-51$.

Mencke, N., \& Jeschke, P. (2002). Therapy and prevention of parasitic insects in veterinary medicine using imidacloprid. Current Topics in Medicinal Chemistry, 2, 701-715.

Michaud, J. P. (1999). Sources of mortality in colonies of brown citrus aphid, Toxoptera citricida. Biocontrol, 44, 347-367.

Michaud, J. P. (2001). Evaluation of green lacewings, Chrysoperla plorabunda (Fitch) (Neurop., Chrysopidae), for augmentative release against Toxoptera citricida (Homoptera: Aphididae) in citrus. Journal of Applied Entomology, 125, 383-388.

Michaud, J. P., \& Browning, H. W. (1999). Seasonal abundance of the brown citrus aphid, Toxoptera citricida (Homoptera: Aphididae) and its natural enemies in Puerto Rico. Florida Entomologist, 82, 425-447.
Mohamed, M. S. (2009). Degradation of methomyl by the novel bacterial strain Stenotrophomonas maltophilia M1. Electronic Journal of Biotechnology, 12(4).

Mommaerts, V., Reynders, S., Boulet, J., Besard, L., Sterk, G., \& Smagghe, G. (2010). Risk assessment for side-effects of neonicotinoids against bumblebees with and without impairing foraging behavior. Ecotoxicology, 19, 207-215.

Nieto-Nafría, J. M., Alonso-Zarazaga, M. A., \& PérezHidalgo, Y. N. (2005). Toxoptera citricida or Toxoptera citricidus? The validity of a specific name (Hemiptera: Aphididae, Aphidini). Nomenclatural Notes. Graellsia, 61, 141-142.

Pascual, S., Cobos, G., Seris, E., \& Gonzalez-Nunez, M. (2010). Effects of processed kaolin on pests and non-target arthropods in a Spanish olive grove. Journal of Pest Science, 83, 121-133.

Sackett, T. E., Buddle, C. M., \& Vincent, C. (2005). Effect of kaolin on fitness and behavior of Choristoneura rosaceana (Lepidoptera: Tortricidae) larvae. Journal of Economic Entomology, 98, 1648-1653.

Saour, G., \& Makee, H. (2004). A kaolin-based particle film for suppression of the olive fruit fly Bactrocera oleae Gmelin (Dip., Tephritidae) in olive groves. Journal of Applied Entomology, 128, 28-31.

SAS Institute. (2005). Userśs Guide: version 9.1.3. Cary: SAS Institute.

Schmuck, R., Schöning, R., Stork, A., \& Schramel, O. (2001). Risk posed to honeybees (Apis mellifera L., Hymenoptera) by an imidacloprid seed dressing of sunflowers. Pest Management Science, 57, 225-238.

Schuster, D. J. (1994). Life-stage specific toxicity of insecticides to parasitoids of Liriomyza trifolii (Burgess) (Diptera: Agromyzidae). International Journal of Pest Management, 40, 191-194.

Sekkat, A. (2008). Les poucerons des agrumes au Maroc. In: Proceeding du Symposium Mediterraneen sur la Protection Phytosanitaire des Agrumes (Rabat, Maroc), pp. 131-145.

Showler, A. T. (2002). Effects of kaolin-based particle film application on boll weevil (Coleoptera: Curculionidae) injury to cotton. Journal of Economic Entomology, 95, 754-762.

Smaili, M. C., Abbassi, M., Boutaleb, J. A., \& Blenzar, A. (2013). Richesse spécifique des ennemis naturels associés aux vergers d'agrumes au Maroc: Intérêt et implication pour la lutte biologique. EPPO Bulletin, 43, 155-166.

Smaili, M. C., Afellah, M., \& Zrida, I. (2001). Contribution à la mise en place d'un système de lute intégrée sur Clémentinier dans la région du Gharb. In: Proceeding du 1er Colloque de l'agriculture sur le thème "Développement Agricole et Recherche Agronomique dans la région du" Bilan et perspectives (Kenitra, Maroc), p. 8.

Smaili, M. C., Blenzar, A., \& Boutaleb, J. A. (2008). Facteurs de mortalité du puceron noir de l'oranger Toxoptera aurantii Boyer de Fonscolombe (Hemiptera: Aphididae) sur agrumes dans la région nord du Gharb. In: Proceeding du Symposium Méditerranéen sur la Protection Phytosanitaire des Agrumes (Rabat, Maroc), pp. 147-159.

Smaili, M. C., Blenzar, A., \& Boutaleb, J. A. (2009). Étude prospective de la fondation, de l'immigration et des facteurs de mortalité des colonies de pucerons noirs de l'oranger Toxoptera aurantii Boyer de Fonscolombe (Hemiptera: 
Aphididae) au nord du Gharb. Journal of Mediterranean Ecology, 35, 5-18.

Smaili, M. C., Blenzar, A., \& Fursch, H. (2010). First record of new species and phenotypes of ladybird (Coleoptera: Coccinellidae) in citrus orchards in Morocco. Faunistic Entomology, 62, 103-107.

Smith, S. F., \& Krischik, V. A. (1999). Effects of systemic imidacloprid on Coleomegilla maculate (Coleoptera: Coccinellidae). Environmental Entomology, 28, 1189-1195.

Solangi, B. K., \& Lohar, M. K. (2007). Effect of some insecticides on the population of insect pests and the predators on okra. Asian Journal of Plant Sciences, 6, 920-926.

Ullah, F., Badshah, H., \& Gul, R. (2005). Evaluation of six different groups of insecticides for the control of citrus psylla Diaphorina citri (Hemiptera: Psyllidae). Songklanakarin Journal of Science and Technology, 27, 17-23.
Van Lenteren, V. H. P., \& Bueno, J. C. (2003). Augmentative biological control of arthropods in Latin America. Biocontrol, 48, 123-139.

Villanueva, R. T., \& Walgenbach, J. (2007). Phenology and management of the apple maggot and effects of Surround on its behavior in North Carolina. Crop Science, 26, 1404-1411.

Vittorio, L. L., \& Delucchi, V. L. (1964). Ravageurs: deuxième partie. In H. Chapot \& V. L. Delucchi (Eds.), Les ravageurs des agrumes: maladies, troubles et ravageurs des agrumes au Maroc (pp. 198-320). Rabat: INRA.

Wyss, E., \& Daniel, C. (2004). Effects of autumn kaolin and pyrethrin treatments on the spring population of Dysaphis plantaginea in apple orchards. Journal of Applied Entomology, 128, 147-149.

Yokomi, R. K., \& Garnsey, S. M. (1987). Transmission of citrus tristeza virus by Aphis gossypii and Aphis citricola in Florida. Phytophylactica, 19, 169-172. 